Goldschmidt 2021 Abstract

https://doi.org/10.7185/gold2021.7121

\section{Recurrent photic zone euxinia in Ediacaran South China Basin revealed by mercury enrichment and isotope compositions}

\author{
ANWEN ZHOU ${ }^{1}$, MORRISON NOLAN ${ }^{2}$, SWAPAN \\ $\mathrm{SAHOO}^{3}, \mathrm{CHADLIN} \mathrm{M}$ OSTRANDER ${ }^{4}$, ARIEL ANBAR $^{5}$, \\ DAVID JONES $^{6}$, SHUHAI XIAO ${ }^{2}$, JIUBIN CHEN $^{1}$ AND \\ WANG ZHENG ${ }^{7}$
}

${ }^{1}$ Tianjin university

${ }^{2}$ Virginia Tech

${ }^{3}$ Equinor ASA

${ }^{4}$ Woods Hole Oceanographic Institution

${ }^{5}$ Arizona State University

${ }^{6}$ Amherst College

${ }^{7}$ Tianjin University

Presenting Author: anwen_97@tju.edu.cn

The Ediacaran Period ( 635-539 Ma) was marked by the emergence and diversification of complex metazoans. The evolutionary dynamics of the Ediacaran marine ecosystem have been linked to ocean redox changes, which have been suggested to be highly dynamic with multipe ocean oxygenation events in a predominantly anoxic global ocean ${ }^{1,2}$. However, the driving factors of the redox evolution in the Ediacaran ocean are still in debate.

Mercury $(\mathrm{Hg})$ concentrations and isotope ratios preserved in ancient sedimentary rocks are emerging as reliable tracers of dramatic changes to Earth's past environments - namely the development of photic zone euxinia (PZE) ${ }^{3}$ and large scale volcanism. One or both of these phenomena could have played an underappreciated role in the rise and fall of the Ediacara biota. To test this hypothesis, we report $\mathrm{Hg}$ concentrations and stable isotope compositions for black shales from the Doushantuo Formation in South China deposited across a large portion of the Ediacaran Period.

We find compelling $\mathrm{Hg}$ isotope evidence for multiple episodes of PZE across the Ediacaran Period. Siginificant negative excursions of mass independent fractionation (MIF) and concurrent positive excursions of mass dependent fractionation of $\mathrm{Hg}$ isotopes occurred during three previously identified ocean oxygenation events (OOEs) ${ }^{1}$. The variation of $\mathrm{Hg}$ MIF positively correlates with $\delta^{34} \mathrm{~S}_{\text {pyrite }}$ in the same samples, suggesting that the negative excursions of $\mathrm{Hg}$ MIF occurred during periods of increased marine sulfate reservoir size. We suggest that the negative excursions of $\mathrm{Hg}$ MIF were driven by recurrent local PZE stimulated by increased sulfate input during OOEs. We also find evidence for volcanic input to the ocean in the terminal Ediacaran period, based on extremely high shale $\mathrm{Hg}$ enrichments ( $>4000 \mathrm{ppb}$ ). Combined effects of PZE and volcanism may have contributed to the evolutionary dynamics of the Ediacaran marine ecosystem.

1. Sahoo, S. K. et al. Oceanic oxygenation events in the anoxic Ediacaran ocean. Geobiology 14, 457-468
(2016).

2. Zhang, F. et al. Extensive marine anoxia during the terminal Ediacaran Period. Sci. Adv. 4, eaan8983 (2018).

3. Zheng, W. et al. Mercury isotope signatures record photic zone euxinia in the Mesoproterozoic ocean. Proc. Natl. Acad. Sci. 115, 10594-10599 (2018). 